\title{
STRATEGI PENINGKATAN KUALITAS LEATHER DENGAN METODE LEAN SIX SIGMA DAN FUZZY FMEA (STUDI KASUS DI SUMBER REJEKI)
}

\section{Strategy to Improve The Quality of Leather with Lean Six Sigma and Fuzzy FMEA Method (Case Study in Sumber Rejeki)}

\author{
Rindha Ayu Roesmasari*, Imam Santoso, Sucipto \\ Jurusan Teknologi Industri Pertanian - Fakultas Teknologi Pertanian - Universitas Brawijaya \\ Jalan Veteran - Malang 65145 \\ *Penulis Korespondensi: email rindha.tstb@gmail.com
}

Disubmit: 6 Februari 2018 Direvisi: 23 Agustus 2018 Diterima: 8 September 2018

\begin{abstract}
ABSTRAK
Kegagalan produk mengandung unsur ketidakpastian yang disebabkan selama proses produksi berlangsung. Metode Lean Six Sigma diharapkan mampu mengidentifikasi waste yang terjadi pada proses produksi dan mendapatkan kategori waste yang berpengaruh pada kualitas kulit samak. Metode FMEA diintegrasikan dengan metode fuzzy untuk mendapatkan prioritas tindakan perbaikan yang lebih baik. Terdapat 8 jenis cacat kulit samak dan 4 jenis cacat prioritas, sekaligus menjadi CTQ yaitu open grain, snei, fish eyes, dan cracking. Metode FMEA menghasilkan nilai RPN tertinggi yaitu open grain dengan nilai 576 dan nilai RPN tertinggi kedua 448 dari jenis cacat fish eyes. Jenis cacat cracking juga memiliki nilai RPN sebesar 448. Fuzzy dapat mengeliminasi nilai RPN yang sama dan menentukan tindakan perbaikan prioritas
\end{abstract}

Kata kunci: Analytical Hierarchy Process; Failure Mode and Effect Analysis; Fuzzy Logic

\begin{abstract}
The occurrence of a product failure contains an element of uncertaintycaused by production processes. Lean Six Sigma method is expected to identify the waste that occurs in the production process and get the category of waste that affects the leather quality.FMEA method is integrated with the fuzzy method to get better improvement action priority. There are eight types of leather defects and four types of defects that become a priority, as well as a CTQ, are open grain, snei, fish eyes, and cracking. In the FMEA method obtained the highest RPN value of 576 on open grain defects type. The second highest RPN value of 448 from fish eyes defect type, with defect cause is differences in chemical material content on the solvent. Defect cracking type with defect cause is too hard paint layer also has RPN value of 448. Calculations using the fuzzy approach can eliminate the same risk priority value in the RPN FMEA value and as a reference for improvement action
\end{abstract}

Keywords: Analytical Hierarchy Process; Failure Mode And Effect Analysis; Fuzzy Logic 


\section{PENDAHULUAN}

Potensi hasil turunan kulit di Indonesia sangat melimpah. Kapasitas produksi industri saat ini belum mampu memenuhi permintaan pasar global. Masalah yang dihadapi yaitu kualitas leather yang dihasilkan belum sesuai dengan standar yang telah ditetapkan oleh perusahaan serta mitra industri terkait. Produk yang belum memenuhi syarat layak ini akan menurunkan kepuasan konsumen.

UD. Sumber Rejeki bergerak pada industri penyamakan kulit dan produk yang dihasilkan adalah leather. Masalah yang dihadapi yaitu tingginya waste akibat produk cacat. Total cacat rata-rata perusahaan saat ini diatas target maksimal cacat yang telah ditentukan perusahaan, yaitu sebesar $2 \%$. Berdasarkan pengamatan dan wawancara pada Agustus 2016 di UD. Sumber Rejeki, didapatkan 8 jenis cacat leather yaitu meliputi cacat open grain, creases/kerut, fish eyes / mata ikan, cracking, urat, pori, snei, dan kutu.

Upaya peningkatan produktivitas termasuk dalam kegiatan inefficiency harus dihilangkan. Kegiatan inefficiency seringkali disebabkan oleh non value added atau yang biasa disebut pemborosan (waste) (Setyawan et $a l ., 2017)$. Tujuan penelitian ini adalah mengidentifikasi pemborosan (waste) yang paling berpengaruh pada proses produksi, dan mengidentifikasi jenis serta penyebab kegagalan produk.

Pendekatan menggunakan metode Lean Six Sigma diharapkan dapat mengatasi permasalahan untuk meminimasi kecacatan produk. Tujuan dari metode ini yaitu mengidentifikasi adanya waste terjadi selama produksi dan diharapkan mendapat kategori dari waste yang berpengaruh pada kualitas leather. Metode Lean Six Sigma diintegrasikan dengan metode FMEA, dapat mengidentifikasi potensi kegagalan yang timbul dalam produksi kulit samak dengan tujuan untuk meminimalkan resiko kegagalan produksi (Puspitasari dan Martanto, 2014).

Metode FMEA diintegrasi dengan fuzzy sehingga didapatkan prioritas tindakan perbaikan lebih baik. Pendekatan fuzzy menggunakan peran para ahli untuk mengevaluasi risiko kegagalan dan memperoleh prioritas tindakan perbaikan (Novina, 2008). Penggunaan metode fuzzy diharapkan nilai Fuzzy Risk Priority Number (FRPN) berbeda jika dibandingkan dengan metode FMEA. Perbandingan kedua nilai dari metode terse- but akan diperoleh urutan FRPN berbeda, hasil perhitungan fuzzy akan memberikan prioritas tindakan perbaikan yang lebih baik (Sukwadi et al., 2017).

\section{METODE}

Penelitian menggunakan metode purposive di UD. Sumber Rejeki, Jl. Teuku Umar No. 5, Kabupaten Magetan bulan Agustus 2016 hingga Desember 2016. Penelitian diawali oleh survei pendahuluan melalui pengamatan secara langsung. Pada tahap ini diperoleh data beberapa masalah yang dihadapi perusahaan, yaitu kecacatan atau kegagalan produk dalam jumlah yang tinggi. Selanjutnya, dilakukan identifikasi penyebab kegagalan. Berdasarkan identifikasi tersebut, pendekatan yang paling sesuai untuk menyelesaikan permasalahan di perusahaan yaitu metode integrasi Lean Six Sigma dan Fuzzy FMEA.

Metode Lean Six Sigma mempunyai tujuan mengidentifikasi pemborosan (waste) yang terjadi pada lantai produksi dan mendapatkan kategori waste yang paling berpengaruh pada kualitas produk leather (Gaspersz dan Fontana, 2011). Cara kerja dari Lean Six Sigma adalah menggunakan tahapan define, measure, analyze, dan improve. Tahapan define menggunakan tool Big Picture Mapping (BPM) diperoleh informasi jenis waste.

Pada tahap measure, mengidentifikasi jenis kegagalan (CTQ), kemudian menggunakan diagram pareto untuk mengidentifikasi jenis cacat paling dominan. Tahap selanjutnya, penentuan level sigma dari produksi leather dilakukan sebagai acuan perbaikan produksi nantinya. Pada tahap analyze dapat diperoleh faktor penyebab kritis terjadinya produk cacat menggunakan tool Root Cause Analysis (RCA). Penyebab cacat yang diperoleh kemudian dilakukan perhitungan nilai Risk Priority Number (RPN) dengan metode FMEA. Nilai RPN diperoleh dengan melakukan perhitungan nilai Severity, Occurrence, dan Detection (SOD). Nilai SOD digunakan sebagai input perhitungan fuzzy.

Failure Mode and Effect Analysis dipergunakan setelah mendapatkan faktor yang mempengaruhi kegagalan atau kecacatan dengan tujuan didapatkan faktor yang memerlukan penanganan lebih lanjut (Gasp- 
ersz, 2012). Analisa FMEA, dapat diketahui penyebab potensial yang memerlukan tindakan perbaikan segera. Nilai RPN didapat dari hasil perkalian nilai severity, occurrence, dan detection. Hasil nilai tertinggi akan menjadi acuan untuk usulan tindakan perbaikan.

Fuzzy merupakan suatu cara yang tepat untuk menentukan suatu ruang input ke dalam suatu ruang output (Kusumadewi dan Purnomo, 2010). Perolehan nilai efek kegagalan (S), peluang kegagalan (O), dan deteksi kegagalan (D) dari tahap FMEA, menjadikan nilai tersebut sebagai input dalam perhitungan fuzzy. Nilai fuzzy RPN tertinggi akan dijadikan usulan tindakan perbaikan (Bourdoucen et al., 2013).

Fuzzy RPN didefinisikan sebagai rata-rata pembobotan dari tiga faktor risiko severity, occurrence, dan detection. Banyak pendapat para ahli bahwa faktor-faktor S, O, dan D tidak mudah untuk dievaluasi secara tepat. Upaya yang signifikan telah dibuat untuk mengevauasi dengan cara linguistik. Penentuan peringkat / prioritas berdasar nilai FRPN, nilai FRPN terbesar merupakan peringkat yang teratas (Bourdoucen et al., 2013). Hasil FRPN digunakan untuk mewakili prioritas untuk tindakan koreksi dengan skala 1-1000. Diagram alir penelitian ditunjukkan pada Gambar 1.

\section{HASIL DAN PEMBAHASAN}

\section{Lean Six Sigma}

Hasil identifikasi waste diperoleh bobot skor waste tertinggi, yaitu waste cacat (defect) dengan total bobot 19. Waste cacat merupakan yang paling berpengaruh terhadap kegagalan produk. Berdasar kriteria dan definisi cacat yang menjadi acuan bagi UD. Sumber Rejeki dan pihak mitra industri ditampilkan pada Tabel 1. Data historis jumlah cacat tiap kategori dapat dilihat pada Tabel 2.

Data historis jumlah cacat pada Tabel 1 dan 2, maka langkah selanjutnya adalah menentukan prioritas jenis cacat menggunakan diagram pareto. Jenis cacat yang memiliki $80 \%$ dari total cacat yaitu jenis cacat open grain, snei, fish eyes, dan cracking.

\section{Failure Mode and Effect Analysis (FMEA)}

Data penyebab cacat diperoleh dari hasil pengolahan Root Cause Analysis (RCA)

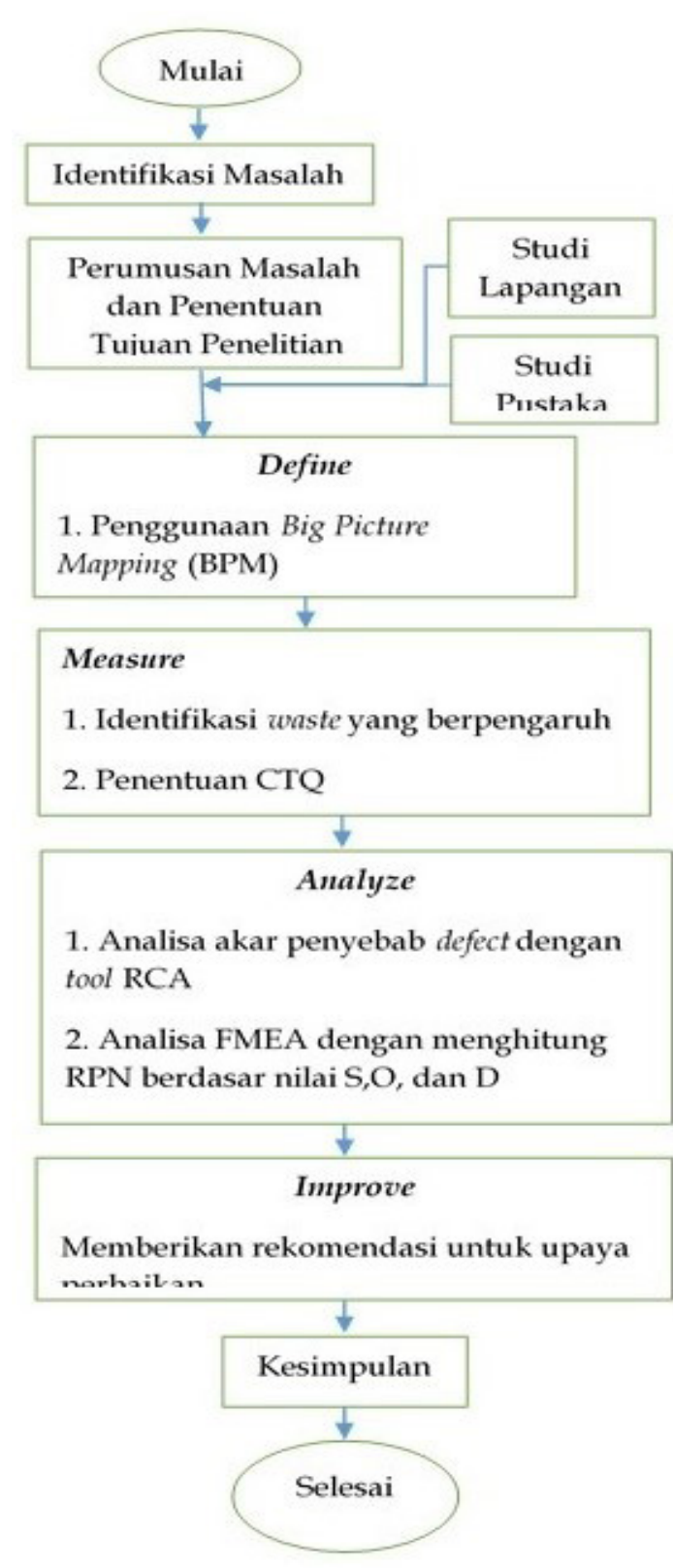

Gambar 1. Diagram alir penelitian

diolah dalam perhitungan FMEA. Severity, occurrence, dan detection diidentifikasi dari hasil brainstorming dan data historis perusahaan. Menilai S, O, dan D diperlukan sebuah skala penilaian dari masing-masing faktor. Setelah diperoleh nilai S, O, dan D maka sebelum melangkah ke tahap selanjutnya menggunakan metode fuzzy, terlebih dahulu menghitung RPN yang ditunjukkan pada Tabel 3. Contoh perkalian nilai S, O, dan D pada cacat open grain untuk penyebab pertama yaitu proses penggaraman tidak sempurna dapat dilihat pada Persamaan 1. 
$\mathrm{RPN}=\mathrm{S} \times \mathrm{O} \times \mathrm{D}$

$=8 \times 7 \times 7=392$

Hasil perhitungan Persamaan 1 didapatkan nilai RPN sebesar 392, kemudian dicari nilai RPN tertinggi untuk dijadikan acuan prioritas tindakan perbaikan. Diketahui RPN tertinggi yaitu 576 didapat dari jenis cacat open grain, dengan penyebab cacat kesalahan pada tahap beam house dan retaining. Nilai RPN tertinggi kedua yaitu 448 dari jenis cacat fish eyes / mata ikan, dengan penyebab cacat perbedaan muatan bahan kimia pada bahan pelarut. Jenis cacat cracking dengan penyebab cacat lapisan cat terlalu keras juga memiliki nilai RPN sebesar 448. Adanya nilai RPN yang sama akan membuat tingkat faktor risiko bisa dikatakan sama, pada kenyataannya tingkat risiko keduanya sangat berbeda. RPN yang sama akan membuat kesulitan dalam menentukan prioritas tindakan perbaikan yang harus dilakukan segera (Bourdoucen et al., 2013).

Tabel 1. Kriteria dan definisi cacat UD. Sumber Rejeki

\begin{tabular}{|c|c|c|}
\hline Jenis Cacat & Gambar & Keterangan \\
\hline Open Grain & & $\begin{array}{l}\text { Cacat berupa lipatan-lipatan permukaan paling luar kulit yang } \\
\text { akan terkelupas dan sudah tidak terdapat lapisan epidermis. }\end{array}$ \\
\hline Creases / kerut & & $\begin{array}{l}\text { Cacat kerutan pada kulit dengan dimensi luas garis kerutan } \geq \\
1 \mathrm{~mm} \text {. }\end{array}$ \\
\hline $\begin{array}{l}\text { Fish Eyes / cacat } \\
\text { mata ikan }\end{array}$ & & $\begin{array}{l}\text { Cacat mata ikan yaitu terdapat titik-titik dengan dimensi luas } \\
\geq 2 \mathrm{~mm} \text {. }\end{array}$ \\
\hline Cracking & & Cacat berupa retak tidak beraturan. \\
\hline Cacat urat & & Cacat berupa tonjolan garis dengan diameter garis $\geq 1 \mathrm{~mm}$. \\
\hline Cacat pori & & Lubang pori-pori terlalu besar dengan dimensi $\geq 1 \mathrm{~mm}$. \\
\hline Snei & & Cacat berupa lapisan bagian tengah tidak rata. \\
\hline Cacat Kutu & & Formasi titik tidak beraturan dengan dimensi luas $\leq 2 \mathrm{~mm}$. \\
\hline
\end{tabular}

Tabel 2. Data historis jumlah cacat leather

\begin{tabular}{clcc}
\hline No. & Jenis Cacat & Jumlah Cacat & Prosentase Cacat \\
\hline 1. & Opengrain & 5632 & $23.36 \%$ \\
2. & Creases/ kerut & 2435 & $10.10 \%$ \\
3. & Fisheyes/ cacat mata ikan & 4677 & $19.40 \%$ \\
4. & Cracking & 3881 & $16.10 \%$ \\
5. & Cacat urat & 750 & $3.11 \%$ \\
6. & Cacat pori & 1013 & $4.20 \%$ \\
7. & Snei & 5124 & $21.25 \%$ \\
8. & Kutu & 598 & $2.48 \%$ \\
\hline Total Cacat & & $\mathbf{2 4 1 1 1}$ & $\mathbf{1 0 0} \%$ \\
\hline
\end{tabular}




\section{Fuzzy}

\section{Menentukan Anggota Tim FMEA}

Peran anggota tim FMEA yaitu untuk menilai efek, penyebab, dan kendali dari 22 ragam kegagalan. Bobot kepentingan ditentukan untuk memberikan perbedaan dalam penilaian FMEA, anggota tim diasumsikan berbeda kepentingan dikarenakan perbedaan keahlian, pengetahuan dan pengalaman dalam menangani proses produksi leather. Bobot kepentingan anggota tim yang terlibat dalam penilaian fuzzy nantinya akan menjadi dasar dalam perhitungan fuzzy. Anggota tim yang berperan dalam menilai FMEA dapat dilihat pada Tabel 4.

\section{Menentukan Nilai Fuzzy untuk Severity, Occurrence, dan Detection}

Nilai severity, occurrence dan detection terlebih dahulu dinilai oleh masing-masing anggota tim melalui penyebaran kuesioner.
Nilai fuzzy untuk faktor $S, O$, dan $D$ didapat dari mengubah nilai FMEA menjadi nilai fuzzy. Contoh jenis cacat open grain dengan penyebab cacat proses penggaraman tidak sempurna, responden pertama memberikan nilai 8 pada faktor severity.

Nilai FMEA menunjukkan kriteria tergolong permasalahan major pada lini produksi. Nilai FMEA tersebut diubah ke dalam nilai fuzzy. Berdasar tabel fuzzy ratings for severity of a failure, angka 8 masuk ke dalam rating Very High (VH). Terdapat perbedaan RPN dan FRPN antara nilai, kategori dan peringkat (Suryana, 2010).

Menentukan Bobot Kepentingan Faktor Severity, Occurrence, dan Detection

Setelah mendapatkan nilai fuzzy untuk faktor $S, O$, dan D, maka selanjutnya adalah mencari nilai bobot kepentingan faktor risiko $\mathrm{S}, \mathrm{O}$, dan $\mathrm{D}$ yang dinilai oleh ang-

Tabel 3. Perhitungan nilai RPN (severity, occurrence, dan detection)

\begin{tabular}{|c|c|c|c|c|c|}
\hline Jenis Cacat & Penyebab & S & $\mathrm{O}$ & D & RPN \\
\hline \multirow{9}{*}{ Open Grain } & Proses penggaraman tidak sempurna & 8 & 7 & 7 & 392 \\
\hline & Waktu penyimpanan kulit mentah terlalu lama & 7 & 6 & 8 & 336 \\
\hline & Terdapat bakteri pada kulit mentah & 7 & 5 & 10 & 350 \\
\hline & Suhu ruang penyimpanan kulit mentah tidak optimal & 6 & 4 & 9 & 216 \\
\hline & Bahan baku lolos inspeksi & 6 & 3 & 8 & 144 \\
\hline & Bahan baku hasil rework & 4 & 7 & 8 & 224 \\
\hline & Jumlah operator kurang & 5 & 1 & 5 & 25 \\
\hline & Operator kurang teliti & 4 & 3 & 6 & 72 \\
\hline & Kesalahan pada tahap beam house dan retaining & 8 & 8 & 9 & 576 \\
\hline \multirow{5}{*}{ Snei } & Cacat bawaan dari kulit sapi & 4 & 4 & 4 & 64 \\
\hline & Kegagalan dalam proses splitting & 7 & 7 & 6 & 294 \\
\hline & Operator bekerja kurang teliti & 4 & 6 & 6 & 144 \\
\hline & Setting alat pemotong kurang tepat & 7 & 2 & 4 & 56 \\
\hline & Seleksi produk secara manual & 5 & 2 & 8 & 80 \\
\hline \multirow{4}{*}{$\begin{array}{l}\text { Fish Eyes } \\
\text { Mata ikan }\end{array}$} & Perbedaan muatan bahan kimia pada bahan pelarut & 8 & 8 & 7 & 448 \\
\hline & $\begin{array}{l}\text { Operator tidak memiliki pengetahuan yang baik terh- } \\
\text { adap jenis bahan pelarut }\end{array}$ & 7 & 5 & 6 & 210 \\
\hline & QC jarang melakukan pengecekan & 5 & 1 & 2 & 10 \\
\hline & Suhu ruang penyimpanan bahan kimia tidak stabil & 3 & 6 & 5 & 90 \\
\hline \multirow{4}{*}{ Cracking } & Lapisan cat terlalu keras & 8 & 7 & 8 & 448 \\
\hline & Komposisi bahan campuran tidak sesuai & 7 & 3 & 3 & 63 \\
\hline & Kesalahan dalam penggunaan alat toogle & 3 & 3 & 5 & 45 \\
\hline & $\begin{array}{l}\text { QC belum memaksimalkan pengecekan dengan opti- } \\
\text { mal }\end{array}$ & 5 & 3 & 2 & 30 \\
\hline
\end{tabular}


gota tim FMEA. Pada FMEA, kepentingan relatif dari faktor risiko diperlakukan dalam tingkat kepentingan yang sama, oleh karena itu, bobot kepentingan relatif faktor $\mathrm{S}, \mathrm{O}$, dan $\mathrm{D}$ akan dinilai menggunakan lima istilah linguistik dan masing-masing mempunyai fungsi keanggotaan sendiri. Hasil penentuan bobot kepentingan faktor $\mathrm{S}, \mathrm{O}$, dan $\mathrm{D}$ dapat dilihat pada Tabel 5. Nilai VH atau Very High yang dinilai oleh panelis ahli pertama pada faktor risiko severity menunjukkan bahwa bobot kepentingan relatif faktor severity adalah sangat tinggi, yang berarti efek kegagalan sangat mempengaruhi proses produksi leather.

\section{Perhitungan Total Penilaian Peringkat Fuzzy untuk Faktor Severity, Occurrence dan Detection}

Perhitungan untuk ragam kegagalan ke-1 sampai dengan ke-10 antara bobot kepentingan faktor $\mathrm{S}$, $\mathrm{O}$, dan $\mathrm{D}$ dengan nilai bobot masing-masing faktor, didapatkan total penilaian peringkat fuzzy, untuk faktor $S$, O, dan D dapat dilihat pada Tabel 6.

Tabel 4. Bobot kepentingan panelis ahli

\begin{tabular}{clc}
\hline No. & Panelis Ahli & Bobot Kepentingan \\
\hline 1 & Owner & $30 \%$ \\
2 & Manager Produksi & $25 \%$ \\
3 & Manager QC & $25 \%$ \\
4 & Staff Produksi & $10 \%$ \\
5 & Staff QC & $10 \%$ \\
\hline
\end{tabular}

Tabel 5. Bobot fuzzy untuk kepentingan relatif faktor S, O, dan D

\begin{tabular}{clccc}
\hline \multirow{2}{*}{ No. } & \multirow{2}{*}{ Panelis Ahli } & \multicolumn{3}{c}{ Bobot Faktor } \\
\cline { 3 - 5 } & & S & O & D \\
\hline 1 & Owner & VH & $\mathrm{M}$ & $\mathrm{L}$ \\
2 & Manager Produksi & $\mathrm{H}$ & $\mathrm{M}$ & $\mathrm{M}$ \\
3 & Manager QC & $\mathrm{H}$ & $\mathrm{L}$ & $\mathrm{L}$ \\
4 & Staff Produksi & $\mathrm{VH}$ & $\mathrm{M}$ & $\mathrm{L}$ \\
5 & Staff QC & $\mathrm{VH}$ & $\mathrm{M}$ & $\mathrm{M}$ \\
\hline
\end{tabular}

Tabel 6. Total penilaian peringkat fuzzy pada faktor severity, occurrence, dan detection

\begin{tabular}{cccc}
\hline $\begin{array}{c}\text { Ragam Penyebab } \\
\text { Kegagalan }\end{array}$ & Severity & Occurrence & Detection \\
\hline R1 & $(6.15 ; 7.15 ; 8.15)$ & $(4.65 ; 5.65 ; 7.1 ; 8.1)$ & $(5.65 ; 6.65 ; 7.65)$ \\
R2 & $(5.8 ; 6.8 ; 7.8)$ & $(2.6 ; 3.6 ; 5.4 ; 6.4)$ & $(6.4 ; 7.4 ; 8.4)$ \\
R3 & $(6.6 ; 7.6 ; 8.6)$ & $(2.8 ; 3.8 ; 5.7 ; 6.7)$ & $(8.3 ; 9.3 ; 10)$ \\
R4 & $(5.6 ; 6.6 ; 7.6)$ & $(1.6 ; 2.6 ; 3.9 ; 4.9)$ & $(7.5 ; 8.5 ; 9.5)$ \\
R5 & $(5.2 ; 6.2 ; 7.2)$ & $(1.7 ; 2.7 ; 4.055 .05)$ & $(6.65 ; 7.65 ; 8.65)$ \\
R6 & $(2.65 ; 3.65 ; 4.65)$ & $(4.65 ; 5.65 ; 7.1 ; 8.1)$ & $(6.65 ; 7.65 ; 8.65)$ \\
R7 & $(3.3 ; 4.3 ; 5.3)$ & $(1 ; 1.7 ; 2.7 ; 2.8)$ & $(4.35 ; 5.35 ; 6.35)$ \\
R8 & $(3.35 ; 4.35 ; 5.35)$ & $(1 ; 1.9 ; 2.9 ; 3.6)$ & $(4.65 ; 5.65 ; 6.65)$ \\
R9 & $(6.65 ; 7.65 ; 8.65)$ & $(5.4 ; 6.4 ; 7.6 ; 8.6)$ & $(7.55 ; 8.55 ; 9.55)$ \\
R10 & $(2.55 ; 3.55 ; 4.55)$ & $(2.1 ; 3.1 ; 4.6 ; 5.65)$ & $(2.4 ; 3.4 ; 4.4)$ \\
\hline
\end{tabular}

Tabel 7. Total bobot kepentingan peringkat fuzzy untuk faktor severity, occurrence, dan detection

\begin{tabular}{lll}
\hline Severity & Occurrence & Detection \\
\hline$(0,625 ; 0,875 ; 1)$ & $(0.1875 ; 0.4375 ; 0.6875)$ & $(0.0875 ; 0.3375 ; 0.5875)$ \\
\hline
\end{tabular}


Perhitungan Total Bobot Kepentingan Fuzzy untuk Faktor Severity, Occurrence, dan Detection

Setelah didapatkan penilaian peringkat fuzzy maka dilakukan perhitungan bobot kepentingan fuzzy untuk faktor S, O, dan D. Total peringkat fuzzy untuk masing-masing faktor S, O, dan D kemudian dilakukan rekapitulasi, dapat dilihat pada Tabel 7.

Perhitungan Rata-rata Peringkat Fuzzy, Bobot Kepentingan Faktor Severity, Occurrence, dan Detection dan Fuzzy Risk Priority Number

Perhitungan fuzzy risk priority number (FRPN) digunakan persamaan seperti terlihat pada Persamaan 2.

$$
\text { FRPN }=\left(\widetilde{R_{l}^{S}}\right) \frac{W^{S}}{W^{S}+W^{0}+W^{D}} x\left(\widetilde{R_{l}^{0}}\right) \frac{W^{0}}{W^{S}+W^{0}+W^{D}} x
$$

Perhitungan Fuzzy Risk Priority Number (FRPN) menggunakan pendekatan fuzzy pada ragam penyebab kegagalan pertama ditunjukkan pada Persamaan 3.

$$
\mathrm{FRPN}=2.771 \times 1.655 \times 1.488=6.826
$$

Nilai 6.826 merupakan nilai Fuzzy Risk Priority Number (FRPN) pada ragam penyebab kegagalan pertama yaitu proses

Tabel 8. Rata-rata peringkat fuzzy, bobot kepentingan faktor severity, occurrence, detection, dan

\begin{tabular}{|c|c|c|c|c|c|c|}
\hline $\begin{array}{l}\text { Ragam } \\
\text { Kegagalan }\end{array}$ & $\begin{array}{l}\text { Rata-Rata } \\
\text { Peringkat } \\
\text { Fuzzy Se- } \\
\text { verity }\end{array}$ & $\begin{array}{l}\text { Rata-Rata } \\
\text { Peringkat } \\
\text { Fuzzy Oc- } \\
\text { currence }\end{array}$ & $\begin{array}{l}\text { Rata-Rata } \\
\text { Peringkat } \\
\text { Fuzzy De- } \\
\text { tection }\end{array}$ & $\begin{array}{l}\text { Bobot } \\
\text { Kepentin- } \\
\text { gan Faktor } \\
\text { Severity }\end{array}$ & $\begin{array}{l}\text { Bobot } \\
\text { Kepentingan } \\
\text { Faktor Oc- } \\
\text { currence }\end{array}$ & $\begin{array}{l}\text { Bobot } \\
\text { Kepentingan } \\
\text { Faktor } \\
\text { Detection }\end{array}$ \\
\hline $\mathrm{R} 1$ & 7.15 & 6.375 & 6.65 & 0.518 & 0.272 & 0.210 \\
\hline R2 & 6.8 & 4.5 & 7.4 & 0.518 & 0.272 & 0.210 \\
\hline R3 & 7.6 & 4.75 & 9.2 & 0.518 & 0.272 & 0.210 \\
\hline $\mathrm{R} 4$ & 6.6 & 3.25 & 8.5 & 0,518 & 0.272 & 0.210 \\
\hline R5 & 6.2 & 3.375 & 7.65 & 0.518 & 0.272 & 0.210 \\
\hline R6 & 3.65 & 6.375 & 7.65 & 0.518 & 0.272 & 0.210 \\
\hline R7 & 4.3 & 2.05 & 5.35 & 0.518 & 0.272 & 0.210 \\
\hline R8 & 4.35 & 2.35 & 5.65 & 0.518 & 0.272 & 0.210 \\
\hline R9 & 7.65 & 7 & 8.55 & 0.518 & 0.272 & 0.210 \\
\hline R10 & 3.55 & 3.875 & 3.4 & 0,518 & 0.272 & 0.210 \\
\hline R11 & 6.4 & 6.625 & 5.4 & 0.518 & 0.272 & 0.210 \\
\hline R12 & 4.35 & 4.5 & 5.65 & 0.518 & 0.272 & 0.210 \\
\hline R13 & 6.55 & 2.2 & 3.65 & 0.518 & 0.272 & 0.210 \\
\hline R14 & 4.55 & 3.375 & 7.8 & 0.518 & 0.272 & 0.210 \\
\hline R15 & 7.4 & 7.25 & 7.25 & 0.518 & 0.272 & 0.210 \\
\hline R16 & 6.3 & 2.325 & 5.4 & 0.518 & 0.272 & 0.210 \\
\hline R17 & 5.45 & 1.9 & 2.25 & 0.518 & 0.272 & 0.210 \\
\hline R18 & 2.55 & 3.75 & 5.25 & 0.518 & 0.272 & 0.210 \\
\hline R19 & 7.3 & 6.375 & 8.7 & 0.518 & 0.272 & 0.210 \\
\hline R20 & 7.1 & 4.75 & 2.5 & 0.518 & 0.272 & 0.210 \\
\hline R21 & 2.5 & 1.825 & 5.35 & 0.518 & 0.272 & 0.210 \\
\hline $\mathrm{R} 22$ & 5.45 & 1.975 & 2.25 & 0.518 & 0.272 & 0.210 \\
\hline
\end{tabular}
FRPN 
penggaraman tidak sempurna. Tahap perhitungan tersebut akan diterapkan pada 21 ragam penyebab kegagalan lainnya. Tahap terakhir dalam menentukan nilai FRPN yaitu seluruh perhitungan untuk keseluruhan 22 ragam penyebab kegagalan, dilakukan pengurutan dari nilai tertinggi sampai dengan nilai terendah. Nilai FRPN tertinggi akan digunakan sebagai prioritas untuk tindakan perbaikan. Penelitian yang telah dilakukan menunjukkan bahwa hasil perankingan untuk nilai FRPN diurutkan berdasar kegagalan tertinggi (Basjir et al., 2011). Hasil perhitungan keseluruhan nilai FRPN dapat dilihat pada Tabel 8.

Tabel 9. Hasil perbandingan nilai RPN FMEA dan RPN fuzzy

\begin{tabular}{|c|c|c|c|c|c|}
\hline $\begin{array}{l}\text { Jenis } \\
\text { Defect }\end{array}$ & Penyebab & $\mathbf{R P N}$ & Prioritas & $\begin{array}{l}\text { Fuzzy } \\
\text { RPN }\end{array}$ & Prioritas \\
\hline \multirow{9}{*}{$\begin{array}{l}\text { Open } \\
\text { Grain }\end{array}$} & $\begin{array}{l}\text { Proses penggaraman tidak sem- } \\
\text { purna }\end{array}$ & 392 & 3 & 6.826 & 5 \\
\hline & $\begin{array}{l}\text { Waktu penyimpanan kulit men- } \\
\text { tah terlalu lama }\end{array}$ & 336 & 5 & 6.186 & 7 \\
\hline & $\begin{array}{l}\text { Terdapat bakteri pada kulit men- } \\
\text { tah }\end{array}$ & 350 & 4 & 6.961 & 4 \\
\hline & $\begin{array}{l}\text { Suhu ruang penyimpanan kulit } \\
\text { mentah tidak optimal }\end{array}$ & 216 & 8 & 5.740 & 8 \\
\hline & Bahan baku lolos inspeksi & 144 & 10 & 5.492 & 9 \\
\hline & Bahan baku hasil rework & 224 & 7 & 4.962 & 11 \\
\hline & Jumlah operator kurang & 25 & 19 & 3.680 & 17 \\
\hline & Operator kurang teliti & 72 & 13 & 3.887 & 16 \\
\hline & $\begin{array}{l}\text { Kesalahan pada tahap beam } \\
\text { house dan retaining }\end{array}$ & 576 & 1 & 7.644 & 1 \\
\hline \multirow{5}{*}{$\begin{array}{l}\text { Cacat } \\
\text { Snei }\end{array}$} & Cacat bawaan dari kulit sapi & 64 & 14 & 3.603 & 18 \\
\hline & Kegagalan dalam proses splitting & 294 & 6 & 6.234 & 6 \\
\hline & Operator bekerja kurang teliti & 144 & 10 & 4.638 & 14 \\
\hline & $\begin{array}{l}\text { Setting alat pemotong kurang te- } \\
\text { pat }\end{array}$ & 56 & 16 & 4.306 & 15 \\
\hline & Seleksi produk secara manual & 80 & 12 & 4.697 & 12 \\
\hline \multirow{4}{*}{$\begin{array}{l}\text { Cacat } \\
\text { Mata } \\
\text { ikan }\end{array}$} & $\begin{array}{l}\text { Perbedaan muatan bahan kimia } \\
\text { pada bahan pelarut }\end{array}$ & 448 & 2 & 7.327 & 2 \\
\hline & $\begin{array}{l}\text { Operator tidak memiliki penge- } \\
\text { tahuan yang baik terhadap jenis } \\
\text { bahan pelarut }\end{array}$ & 210 & 9 & 4.651 & 13 \\
\hline & $\begin{array}{l}\text { QC jarang melakukan pengece- } \\
\text { kan }\end{array}$ & 10 & 20 & 3.398 & 20 \\
\hline & $\begin{array}{l}\text { Suhu ruang Penyimpanan bahan } \\
\text { kimia tidak stabil }\end{array}$ & 90 & 11 & 3.295 & 21 \\
\hline \multirow{4}{*}{ Cracking } & Lapisan cat terlalu keras & 448 & 2 & 7.300 & 3 \\
\hline & $\begin{array}{l}\text { Komposisi bahan campuran tidak } \\
\text { sesuai }\end{array}$ & 63 & 15 & 5.113 & 10 \\
\hline & $\begin{array}{l}\text { Kesalahan dalam penggunaan } \\
\text { alat toogle }\end{array}$ & 45 & 17 & 2.692 & 22 \\
\hline & $\begin{array}{l}\text { QC belum memaksimalkan } \\
\text { pengecekan dengan optimal }\end{array}$ & 30 & 18 & 3.434 & 19 \\
\hline
\end{tabular}


Hasil nilai FRPN tertinggi dipilih karena menunjukkan penyebab cacat leather harus segera dilakukan tindakan perbaikan. Berdasarkan Tabel 8, terlihat bahwa prioritas pertama adalah kesalahan pada tahap beam house dan retaining. Nilai FRPN untuk ragam penyebab kegagalan akan dipilih yang termasuk dalam kategori sedang $(\mathrm{M})$ sampai dengan sedang-tinggi (M-H) yaitu kesalahan pada tahap beam house dan retaining, perbedaan muatan bahan kimia pada bahan pelarut, lapisan cat terlalu keras, terdapat bakteri pada kulit mentah, dan proses penggaraman tidak sempurna.

Penggunaan pendekatan metode fuzzy dapat menghilangkan nilai prioritas resiko yang sama seperti terlihat pada nilai RPN FMEA dan sebagai acuan tindakan perbaikan. Jika dibandingkan dengan metode fuzzy, diperoleh nilai RPN yang berbeda satu sama lain dan spesifik, sehingga hanya diperoleh satu nilai tertinggi untuk dilakukan tindakan perbaikan. Hasil perbandingan nilai RPN FMEA dan fuzzy dapat dilihat pada Tabel 9.

Menurunkan jumlah produk cacat yaitu memberi usulan perbaikan kepada perusahaan. Pada pendekatan metode fuzzy dapat diketahui penyebab cacat kritis dengan melihat nilai fuzzy RPN tertinggi. Hasil rekap nilai fuzzy RPN pada Tabel 7, maka diambil 5 penyebab cacat yang memiliki nilai tertinggi dari 22 macam ragam kegagalan. Peringkat pertama sampai dengan lima berdasar rangking prioritas risiko, maka akan dilakukan beberapa alternatif strategitindakan perbaikan terhadap proses produksi sesuai dengan kondisi dari perusahaan sendiri.

1. Penentuan strategi tindakan perbaikan dari penyebab kegagalan kesalahan tahap beam house dan retaining hasil dari brainstorming Owner, Manager Produksi, dan Manager QC meliputi evaluasi hasil dari setiap perlakuan, penggunaan konsentrasi bahan baku dan bahan tambahan dalam jumlah yang tepat, training harus dilakukan secara efektif pada tenaga kerja lama atau baru, dan penerapan SOP dalam setiap prosedur.

2. Penentuan strategi tindakan perbaikan dari kesalahan perbedaan muatan bahan kimia dalam bahan pelarut meliputi penggunaan SOP berkaitan dengan bahan kimia dan bahan pelarut yang digunakan, kerjasama QC dan operator produksi lebih diperketat, dan penambahan supplier bahan kimia.
3. Penentuan strategi tindakan perbaikan dari lapisan cat terlalu keras meliputi meningkatkan keterampilan pekerja bagian pengecatan, setting alat roll coating dengan tepat, penjadwalan perawatan mesin spray, padding, dan roll coating, dan pemberian silikon serta karnoba.

4. Penentuan strategi tindakan perbaikan dari lapisan cat terlalu keras meliputi inspeksi dalam pemilihan bahan baku, pemilihan supplier diperketat sesuai dengan standar yang ditetapkan, bahan baku segera diproses / tidak disimpan dalam waktu yang lama, dan sterilisasi gudang bahan baku.

5. Penentuan strategi tindakan perbaikan dari proses penggaraman tidak sempurna meliputi mengatur waktu penggaraman dengan tepat, harus menggunakan jumlah dan konsentrasi garam yang tepat, dan proses penggaraman harus dilakukan lebih rata.

\section{SIMPULAN}

Produk cacat leather meliputi open grain, creases, fish eyes, cracking, urat, pori, snei, dan kutu. Perhitungan menggunakan diagram pareto terdapat 4 jenis cacat, menjadi prioritas sekaligus menjadi CTQ yaitu open grain, snei, fish eyes, dan cracking. Ragam penyebab kegagalan yaitu kesalahan tahap beam house dan retaining, perbedaan muatan bahan kimia pada bahan pelarut, lapisan cat terlalu keras, terdapat bakteri pada kulit mentah, dan proses penggaraman tidak sempurna. Alternatif strategi tindakan perbaikan terhadap proses produksi sesuai dengan kondisi dari perusahaan sendiri.

\section{DAFTAR PUSTAKA}

Basjir, M., Supriyanto, H., Suef, M. 2011. Pengembangan Model Penentuan Prioritas dan Rekomendasi Perbaikan Terhadap Mode Kegagalan Komponen dengan Metodologi FMEA, Fuzzy dan TOPSIS yang terintegrasi. Skripsi. ITS, Surabaya

Bourdoucen, -H., Al-Azani, -F., Al-Naamany, -A., 2013. Study of fuzzy logic-based 
Jurnal Teknologi Pertanian Vol. 19 No. 3 [Desember 2018] 183-192

Strategi Peningkatan Kualitas Leather dengan Metode Lean Six Sigma [Roesmasari dkk]

controller for diff-serv bandwidth broking. Journal of Computing and Information Technology. 21(1), 1-11. https:// doi.org/10.2498/cit.1002128

Gaspersz, V., 2012. All in One Management Toolbook, Contoh Aplikasi Pada Bisnis dan Industry Modern. Gramedia pustaka utama, Jakarta

Gaspersz, V., Fontana, A. 2011. Lean Six Sigma for Manufacturing and Service Industries. Vinchristo Publication, Bogor

Kusumadewi, S., Purnomo, H. 2010. Aplikasi Logika Fuzzy untuk Pendukung Keputusan. Graha Ilmu, Yogyakarta

Novina, L. 2008 Analisa Kegagalan Pada Proses Produksi Susu Cair Indomilk dengan Root Cause Analysis (RCA) dan Grey FMEA. Skripsi. ITS. Surabaya

Puspitasari, N, -B., Martanto, -A., 2014. Penggunaan FMEA dalam mengidentifikasi resiko kegagalan proses produksi sarung ATM (alat tenun mesin) (studi kasus PT ASAPUTEX Jaya Tegal). J@ TI. 9(2), 93-98. https:/ / ejournal.undip. ac.id/index.php/jgti/article/viewFile/6855/5717

Sukwadi, -R., Wenehenubun, -F., Wenehenubun, T, -W., 2017. Pendekatan fuzzy FMEA dalam analisis faktor risiko kecelakaan kerja. Jurnal Rekayasa Sistem Industri. 6(1), 29-38. https:// doi.org/10.26593/jrsi.v6i1.2425.29-38

Suryana. 2010. Metode Penelitian Model Praktis Penelitian Kuantitatif dan Kualitatif. UPI, Bandung

Setyawan, Y, P, -P., Handayani, N, -U., Suliantoro, -H., 2017. Analisis pemborosan (waste) material pada proses produksi aqua kemasan $240 \mathrm{ml}$ di PT. tirta investama klaten. Industrial Engineering Online Journal. 6(2), 1-9. https:/ / ejournal3.undip.ac.id/index. $\mathrm{php} /$ ieoj/article/view/16481 